\title{
Contrasting geochemical signatures of Devonian and Permian granitoids from the Tseel Terrane, SW Mongolia
}

\author{
Ulziiburen BURENJARGAL ${ }^{1 *}$, Atsushi OKAMOTO², Noriyoshi TSUCHIYA², Masaoki UNO², \\ Kenji HORIE ${ }^{3,4}$, Tomokazu HOKADA ${ }^{3}$ \\ ${ }^{1}$ School of Geology and Mining Engineering, Mongolian University of Science and Technology, Ulaanbaatar 46/520, Mongolia; \\ burenjargal@must.edu.mn \\ ${ }^{2}$ Graduate School of Environmental Studies, Tohoku University, Sendai 980-8579, Japan \\ ${ }^{3}$ National Institute of Polar Research, Tachikawa, Tokyo 190-8518, Japan \\ ${ }^{4}$ Department of Polar Science, SOKENDAI (The Graduate University for Advanced Studies), Tachikawa, Tokyo 190-8518, Japan \\ *Corresponding author
}

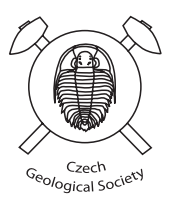

The Tseel Terrane in SW Mongolia contains abundant Devonian and Permian granitoid intrusions that formed during the evolution of the Central Asian Orogenic Belt (CAOB). The newly obtained SHRIMP zircon ages for three granitoid

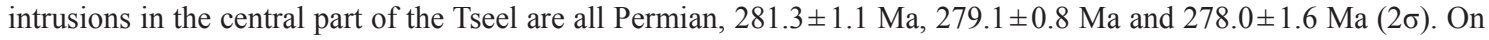
the $\mathrm{La} / \mathrm{Gd}$ vs. La diagram the granitoids are classified into two groups, whereby Group 1 has higher La concentrations and La/Gd ratios than Group 2. Although the number of dated samples is limited, Devonian and Permian ages are assumed for the Group 1 and 2, respectively. Group 1 shows enrichment in Large Ion Lithophile Elements, as well as negative anomalies for High Field Strength Elements such as Nb, Hf, and Zr in Primitive mantle-normalized spiderplots. This may indicate a contribution of slab-derived fluids to melting or anatexis of upper continental crust. The Group 2 is poorer in $\mathrm{Ba}, \mathrm{Eu}, \mathrm{Sr}, \mathrm{Ti}$ and LREE indicating fractionation of feldspar, $\pm \mathrm{Bt}$ with Mnz and opaque mineral(s). These findings, combined with the results of previous petrological and chronological studies, suggest that the Devonian granitoids were generated by relatively deep melting, within garnet stability field; they were emplaced at mid-crustal levels, during regional high- $T$ and low- $P$ metamorphism. On the other hand, the Permian intrusions solidified from a highly fractionated melt, probably in a relatively shallow crust.

Keywords: granitoids, geochemical characteristics, Tseel Terrane, SW Mongolia

Received: 27 July, 2015; accepted: 22 February, 2016; handling editor: K. Schulmann

\section{Introduction}

The Central Asian Orogenic Belt (CAOB) is one of the largest orogens worldwide, and extends from the Urals in the west through Kazakhstan, Mongolia, southern Siberia, northern China to the Okhotsk Sea in the east (Fig. 1a). The CAOB contains several high-temperature metamorphic zones associated with the intrusion of granitoids (Kozakov et al. 2002; Wei et al. 2007; Windley et al. 2007; Burenjargal et al. 2014; Broussolle et al. 2015). The geochemical characteristics are of special importance for constraining the tectonic setting of these intrusions and their relations to the high-T/low- $P$ metamorphism that occurred during the evolution of the CAOB.

The immense region of Mongolia makes up much of the CAOB (Fig. 1a) and is subdivided into the northern and southern domains separated by the Main Mongolian Lineament (MML; Fig. 1b). The northern domain contains many granitic plutons of various ages and compositions, occurring in association with Precambrian and Lower Paleozoic metamorphic rocks (Badarch et al. 2002). The southern one is composed of middle to Late
Paleozoic arc-related assemblages (Zonenshain et al. 1975; Badarch et al. 2002) and fragments of ophiolites and serpentinite mélanges (Rippington et al. 2008).

The Tseel Terrane is located in SW Mongolia immediately south of the MML (Fig. 1b), and it extends eastwest for more than $600 \mathrm{~km}$. The Tseel Terrane is a high- $T$ and low- $P$ crustal segment of an early Paleozoic arc system within the CAOB (Kozakov et al. 2002; Burenjargal et al. 2012, 2014; Jiang et al. 2012; Fig. 1). Burenjargal et al. (2014) proposed that two metamorphic events occurred in the Tseel Terrane: the Silurian (450-400 Ma) high-P/low- $T$ metamorphism, and the Devonian (377 \pm $30 \mathrm{Ma}$ ) low- $P$ and high- $T$ metamorphism. The later event suggests elevated geotherms during the Devonian caused by the ongoing intrusion of granitoid bodies and/or by radioactive heat production subsequent to the granitoid intrusions (Burenjargal et al. 2014). Previous studies have examined the petrology of metamorphic rocks and geochronology of few granitoids in the Tseel area, whereas geochemical studies of the granitoids are lacking.

In this contribution, we investigate the age and geochemistry of granitoids in the Tseel area in order to un- 


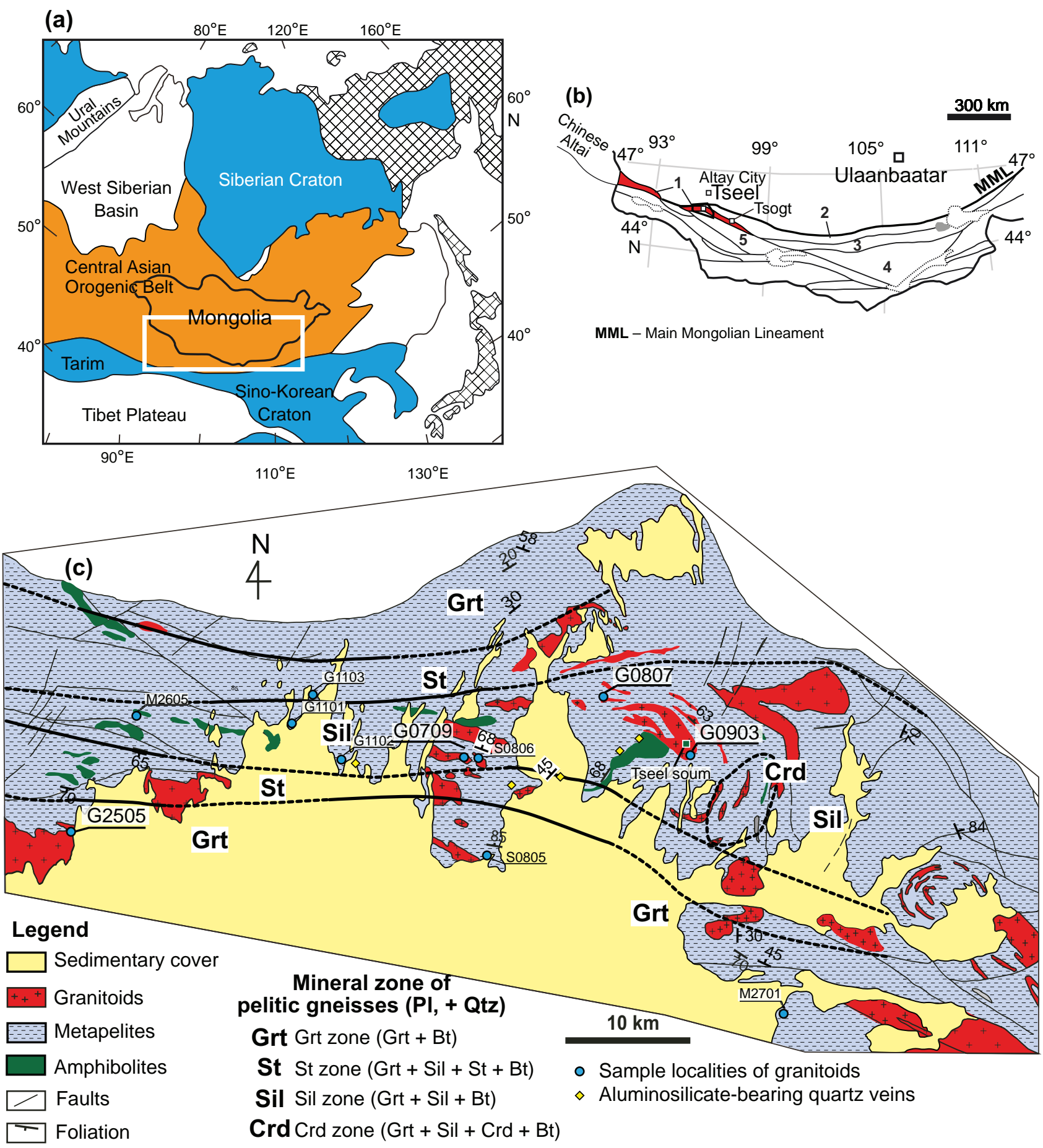

Fig. 1a - Main tectonic components of the Central Asian Orogenic Belt (CAOB). Blue areas indicate Archean to Mesoproterozoic cratons (modified after Jahn et al. 2000). b - Tectonostratigraphic map of southern Mongolia: 1 - Tseel Terrane, 2 - Gobi-Altai Terrane, 3 - Mandalovoo Terrane, 4 Gurvansaikhan Terrane, 5 - Edren Terrane (Badarch et al. 2002). MML, Main Mongolian Lineament. c - Geological map of the Tseel area showing the locations of granitoid samples analyzed in this study. Mineral zones are after Burenjargal et al. (2014): Grt = garnet zone, $\mathrm{St}=$ staurolite zone, Sil = sillimanite zone, and Crd $=$ cordierite zone.

derstand their nature and the tectonic setting of the Tseel Terrane. We present differences in geochemical characteristics between Devonian and Permian granitoids, and discuss their relation to the metamorphic development of the Tseel area.

\section{Geological setting}

The CAOB extends from the Urals to the Pacific Ocean and from the Siberian and East European (Baltica) cratons to the North China (Sino-Korean) and Tarim 
cratons (Şengör et al. 1993; Jahn et al. 2000; Windley et al. 2007). The CAOB was formed through the accretion of island arcs, ophiolites, oceanic islands, seamounts, accretionary wedges, and microcontinents at a convergent margin (e.g. Khain et al. 2002; Windley et al. 2007). The Tseel Terrane in SW Mongolia is characterized by high$T$ metamorphism and abundance of granitoid intrusions (Kozakov et al. 2002; Burenjargal et al. 2012, 2014).

The Tseel area, which lies in the eastern block of the Tseel Terrane (Fig. 1b), is composed mainly of pelitic gneisses and amphibolites intruded by numerous granitoids (Figs 1c and 2). The rocks in this area mainly have an E-W striking foliation that locally curves around granitoid bodies (Fig. 1c).

Four mineral zones have been identified in the Tseel area based on index minerals in the metapelites: garnet, staurolite, sillimanite, and cordierite (Fig. 1c; Burenjargal et al. 2014). The distribution of mineral zones is symmetrical about an $\mathrm{E}-\mathrm{W}$ trending axis, with the high-grade sillimanite assemblages occurring along a central strip, and the grade decreasing to a sillimanite-absent biotite \pm garnet assemblage to the north and south (Fig. 1c). Petrological analyses of the pelitic gneisses in the Tseel area have revealed two metamorphic events: an earlier high- $P$ and low- $T$ metamorphism (kyanite stability field) and a later low- $P$ and high- $T$ metamorphism (sillimanite stability field) (Burenjargal et al. 2012, 2014). The former event is mainly recorded in the garnet zone, and the latter in the sillimanite and cordierite zones. The garnet in the staurolite zone preserves imprint of both metamorphic stages (Burenjargal et al. 2012, 2014). Granitoids are common in the sillimanite and cordierite zones, but rare in the garnet zone (Fig. 1c; fig. 14 of Burenjargal et al. 2014). The sillimanite and staurolite zones of the Tseel area are cut by aluminosilicate-bearing quartz veins (Burenjargal et al. 2012, 2014). These veins contain all three aluminosilicate polymorphs, which formed in the order of $\mathrm{Ky} \rightarrow \mathrm{Sil} \rightarrow$ And (Burenjargal et al. 2012, 2014).

\section{Analytical techniques}

\subsection{Whole-rock geochemistry}

Major and trace elements were determined by ICP-AES and ICP-MS at the Graduate School of Environmental Studies, Tohoku University, Japan. Half a gram of each finely ground sample was treated with $10 \mathrm{ml}$ of perchloric acid $\left(\mathrm{HClO}_{4}\right)$ and nitric acid $\left(\mathrm{HNO}_{3}\right)(1: 1$ mixture), followed by a double treatment with $15 \mathrm{ml}$ of $\mathrm{HClO}_{4}+$ hydrofluoric acid (HF) (1:2 mixture) in a polytetrafluoroethylene (PTFE) beaker on a hot plate. The residue was heated with $5 \mathrm{ml}$ of $\mathrm{HNO}_{3}$ and dissolved by the addition of $30-50 \mathrm{ml}$ of $\mathrm{H}_{2} \mathrm{O}$ with gentle boiling and finally made up to $100 \mathrm{ml}$. The final solutions were stored in plastic bottles until measurement. After a 10-100× dilution, the acid digests were analyzed by ICP-MS for trace elements. Indium was used as an internal standard (Yamasaki 1996, 2000). The working standards were prepared from a series of SPEX MultiElement Plasma Standards (XSTC-1, XSTC-7, XSTC-8, and XSTC-13) supplied by SPEX Industries (New Jersey, USA). A quadrupole type ICP-MS, (HP-4500, Hewlett Packard, now Agilent Technologies, Palo Alto, CA, USA) was used for analyzing most of the trace elements (>0.1 $\mathrm{mg} \mathrm{kg}^{-1}$ sample).

\subsection{Zircon dating}

The U-Pb dating of the samples was carried out using a SHRIMP II at the National Institute of Polar Research (NIPR), Japan. Zircon grains for SHRIMP analyses were separated from rock samples (about $500 \mathrm{~g}$ ) using standard crushing, grinding, sieving, and heavy-liquid and magnetic separation techniques, followed by hand picking under a binocular microscope. We carried out magnetic separation twice with ferrite magnet and neodymium
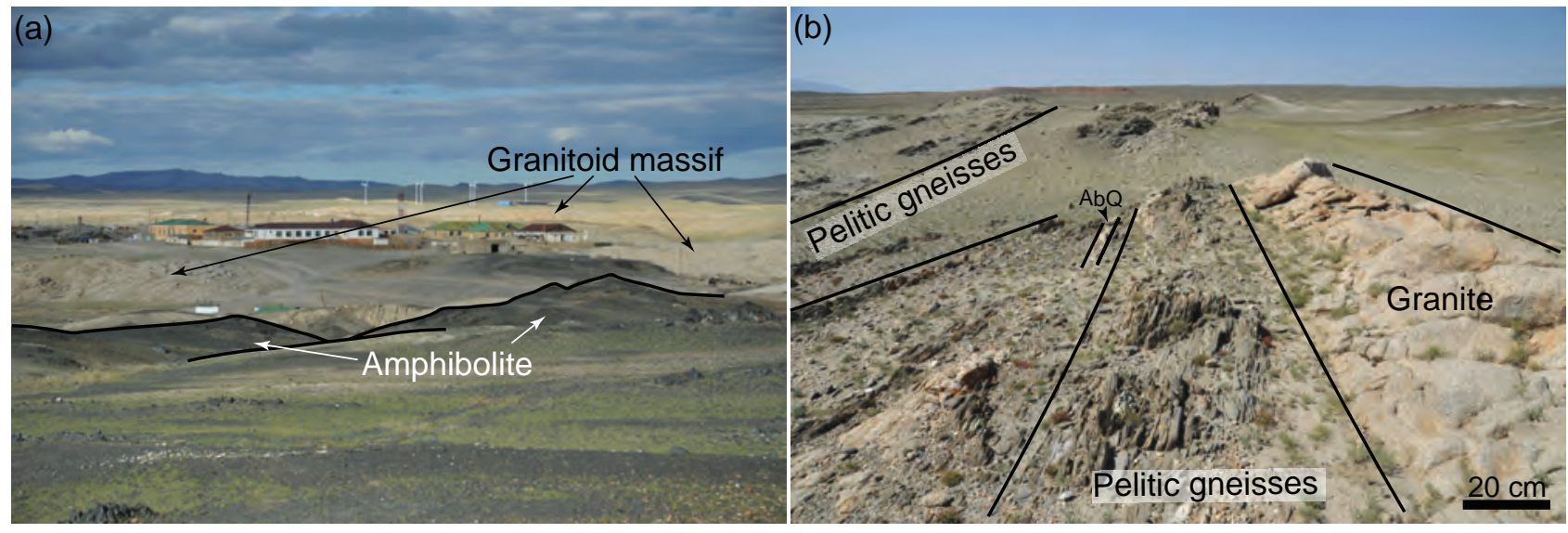

Fig. 2 Field photographs of the rocks in the Tseel area. $\mathbf{a}$ - Granitoid intrusion at Tseel town and its contact with amphibolite. $\mathbf{b}-$ Granite interlayered with pelitic gneisses (AbQ - aluminosilicate-bearing quartz vein). 

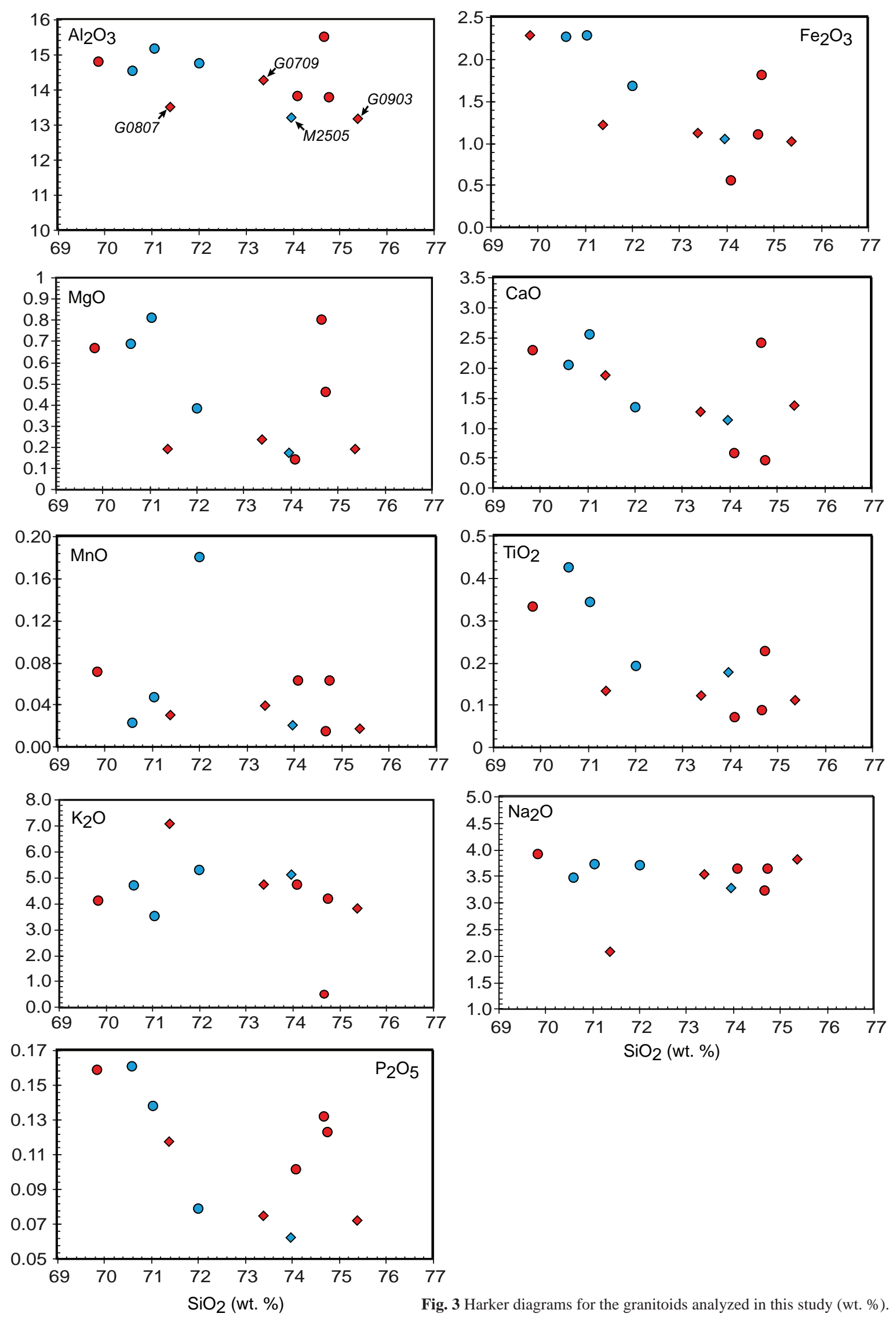


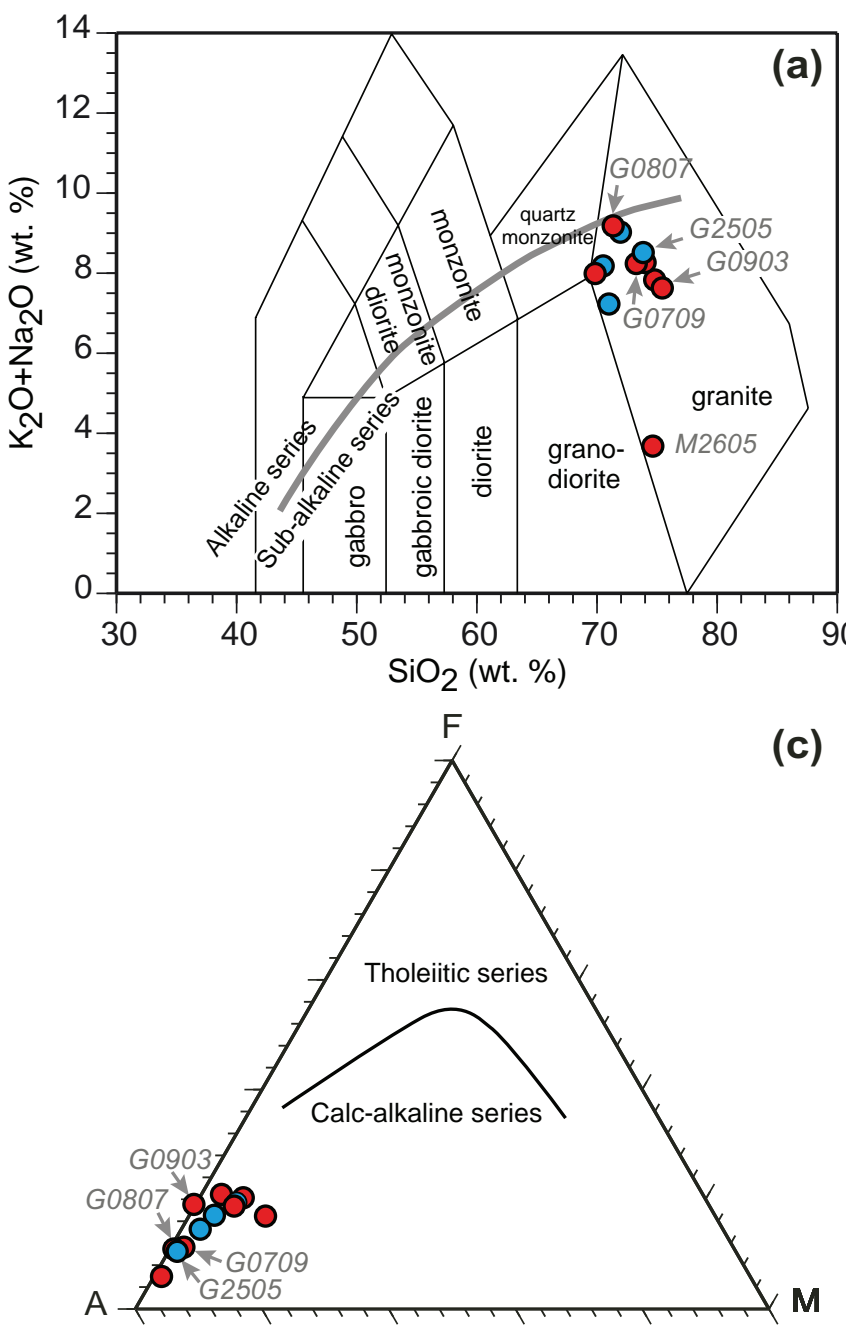

magnet, respectively. Zircon grains isolated from each sample were mounted together with standards in an epoxy resin disc. After curing, the discs were polished to reveal the internal parts of the mounted grains. To investigate the internal structures of individual zircon crystals, backscattered electron (BSE) and cathodoluminescence (CL) images were obtained using a JEOL JSM-5900LV scanning electron microscope (SEM) housed at the NIPR. These images were then used as guides in choosing sites for analysis. Prior to analysis, the surfaces of each grain mount were washed with $2 \% \mathrm{HCl}$ to remove any lead contamination (Amelin et al. 2003) and then coated with a thin $(\sim 100 \AA)$ layer of gold. During analysis of zircon in polished grain mount, an $\mathrm{O}^{2-}$ primary ion beam was used to sputter analytical spots of $\sim 20 \mu \mathrm{m}$ in diameter. The procedures for $\mathrm{Pb}$ and $\mathrm{U}$ isotopic analyses of zircon followed closely those outlined in Compston et al. (1984), Williams (1998), and Horie et al. (2006). In this study, TEMORA2 $\left({ }^{206} \mathrm{~Pb} /{ }^{238} \mathrm{U}\right.$ age $=416.8 \mathrm{Ma}$; Black et al. 2004) and SL13 (U concentration 238 ppm; Claoué-Long et al. 1995) were used as calibration standard materials for the $\mathrm{U}-\mathrm{Pb}$ analyses and concentration standard for $\mathrm{U}$ analysis,

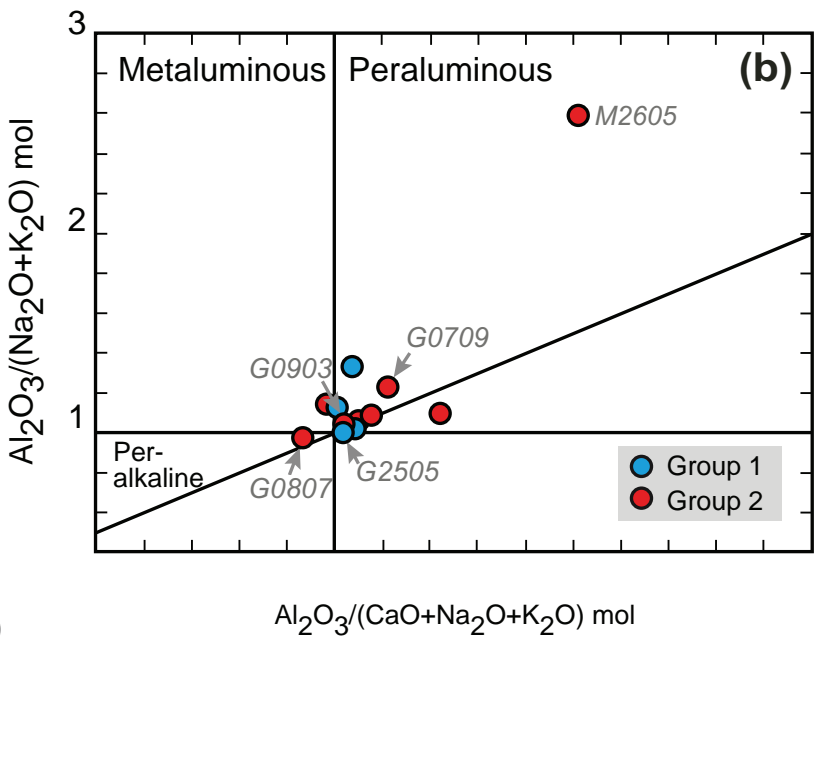

Fig. 4a - Total alkali-silica diagram (TAS) for the studied granitoids, Middlemost (1994). b - A/CNK vs. A/NK plot (Maniar and Piccoli 1989). c - AFM diagram. The boundary between the tholeiitic and calc-alkaline series is after Irvine and Baragar (1971).

respectively. The $\mathrm{U}-\mathrm{Pb}$ data were reduced in a manner similar to that described by Williams (1998), using the SQUID2 add-in for Microsoft Excel (Ludwig 2009). Common $\mathrm{Pb}$ was corrected on the basis of the measured ${ }^{204} \mathrm{~Pb}$ content and the two-stage model of terrestrial $\mathrm{Pb}$ isotope evolution proposed by Stacey and Kramers (1975). Therefore, the individual SHRIMP U-Pb ages presented in this study are all calculated after this initial correction for common $\mathrm{Pb}$, and the final pooled ages were then calculated using Isoplot/Ex software (Ludwig 2008). The analytical uncertainty for individual SHRIMP analyses is reported at the $1 \sigma$ level, and errors on final pooled ages are quoted at the $2 \sigma$ level.

\section{Results}

\subsection{Petrology}

In the Tseel area, granitoids intruded to pelitic gneisses and amphibolites. The granitoids are even grained, and occur as large, kilometer-scale massive bodies or as lay- 
ers up to several meters thick (Fig. 2a-b). Their main constituents are (in vol. \%): quartz (20-40), plagioclase (22-42), K-feldspar (10-18), biotite (4-14), minor garnet, amphibole and muscovite with accessory magnetite, zircon, apatite and monazite. Plagioclase forms subhedral crystals $0.6-0.8 \mathrm{~mm}$ across. K-feldspar occurs as anhedral grains, $0.5-1 \mathrm{~mm}$ in size, associated with quartz, plagioclase, biotite and muscovite. Biotite flakes are large, $0.3-0.5 \mathrm{~mm}$ in size. Garnet occurs as rare and small crystals up to $0.3 \mathrm{~mm}$ across.

\subsection{Whole-rock geochemistry}

Eleven granitoid samples were selected for major- and trace-element analyses. The localities of the analyzed samples in the Tseel area are shown in Fig. 1c.

\subsubsection{Major elements}

The $\mathrm{SiO}_{2}$ contents of the granitoids range from 69.82 to 75.73 wt. \% (Tab. 1; Fig. 3). Harker diagrams reveal negative correlations between $\mathrm{SiO}_{2}$ and $\mathrm{Al}_{2} \mathrm{O}_{3}, \mathrm{Fe}_{2} \mathrm{O}_{3} \mathrm{t}, \mathrm{MgO}$, $\mathrm{CaO}, \mathrm{MnO}, \mathrm{TiO}_{2}$, and $\mathrm{K}_{2} \mathrm{O}$ (Fig. 3). The $\mathrm{Na}_{2} \mathrm{O}$ content is largely constant regardless the $\mathrm{SiO}_{2}$ value; the $\mathrm{K}_{2} \mathrm{O}$ / $\mathrm{Na}_{2} \mathrm{O}$ ratio (by weight) shows a wide range from 0.16 to 3.40 (Tab. 1). The $\mathrm{Mg}$ number [molar $100 \times \mathrm{MgO} /(\mathrm{MgO}$ $+\mathrm{FeO}_{\text {total }}$ )] ranges from 23.2 to 59.0 (Tab. 1). The total alkali-silica (TAS; Middlemost 1994) diagram indicates that all the granitoid samples are subalkaline granites (Fig. 4a). Except for sample M2605, which shows higher $\mathrm{Al}_{2} \mathrm{O}_{3}$ and lower $\mathrm{K}_{2} \mathrm{O}$ contents (Tab. 1), the granitoid samples yield Shand's index $\left\{\mathrm{A} / \mathrm{CNK},\left[\mathrm{molar} \mathrm{Al}_{2} \mathrm{O}_{3} /(\mathrm{CaO}\right.\right.$ $\left.\left.\left.+\mathrm{Na}_{2} \mathrm{O}+\mathrm{K}_{2} \mathrm{O}\right)\right]\right\}$ values of $0.93-1.22$, and $\mathrm{A} / \mathrm{NK}$ [molar $\left.\mathrm{Al}_{2} \mathrm{O}_{3} /\left(\mathrm{Na}_{2} \mathrm{O}+\mathrm{K}_{2} \mathrm{O}\right)\right]$ values of $1.21-1.52$ (Fig. $\left.4 \mathrm{~b}\right)$. The felsic granitoids are poor in ferromagnesian elements and rich in alkalis in the AFM diagram, and thus cannot be used to decipher their calc-alkaline vs. tholeiitic character (Irvine and Baragar 1971) (Fig. 4c).

\subsubsection{Trace elements}

On the $\mathrm{Y}+\mathrm{Nb}$ vs. Rb tectonic discriminant diagram (Pearce et al. 1984), almost all the granitoid samples plot in the volcanic-arc granite field (Fig. 5a), except for sample G1103 that falls in the within-plate granite field.

On the La vs La/Gd diagram (Fig. 5b), the granitoid samples form two clusters: Group 1 is characterized by higher La and La/Gd compared to Group 2.

The Y contents of the granitoid samples are less than $25 \mathrm{ppm}$ (Fig. 5c) and the Sr content ranges from 64 to $531 \mathrm{ppm}$ (Tab. 2). For Group 1 samples, the Sr/Y ratio broadly increases with decreasing Y contents (Fig. 5c), which results in a shift from the field for normal volcanic-

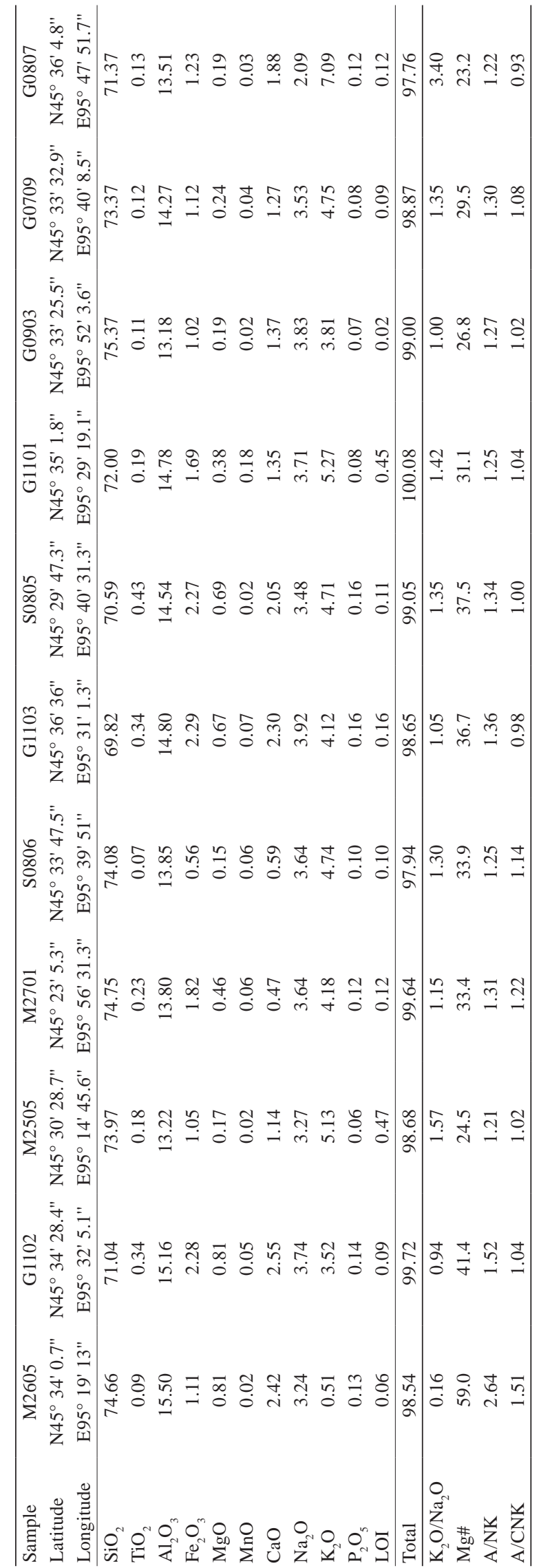



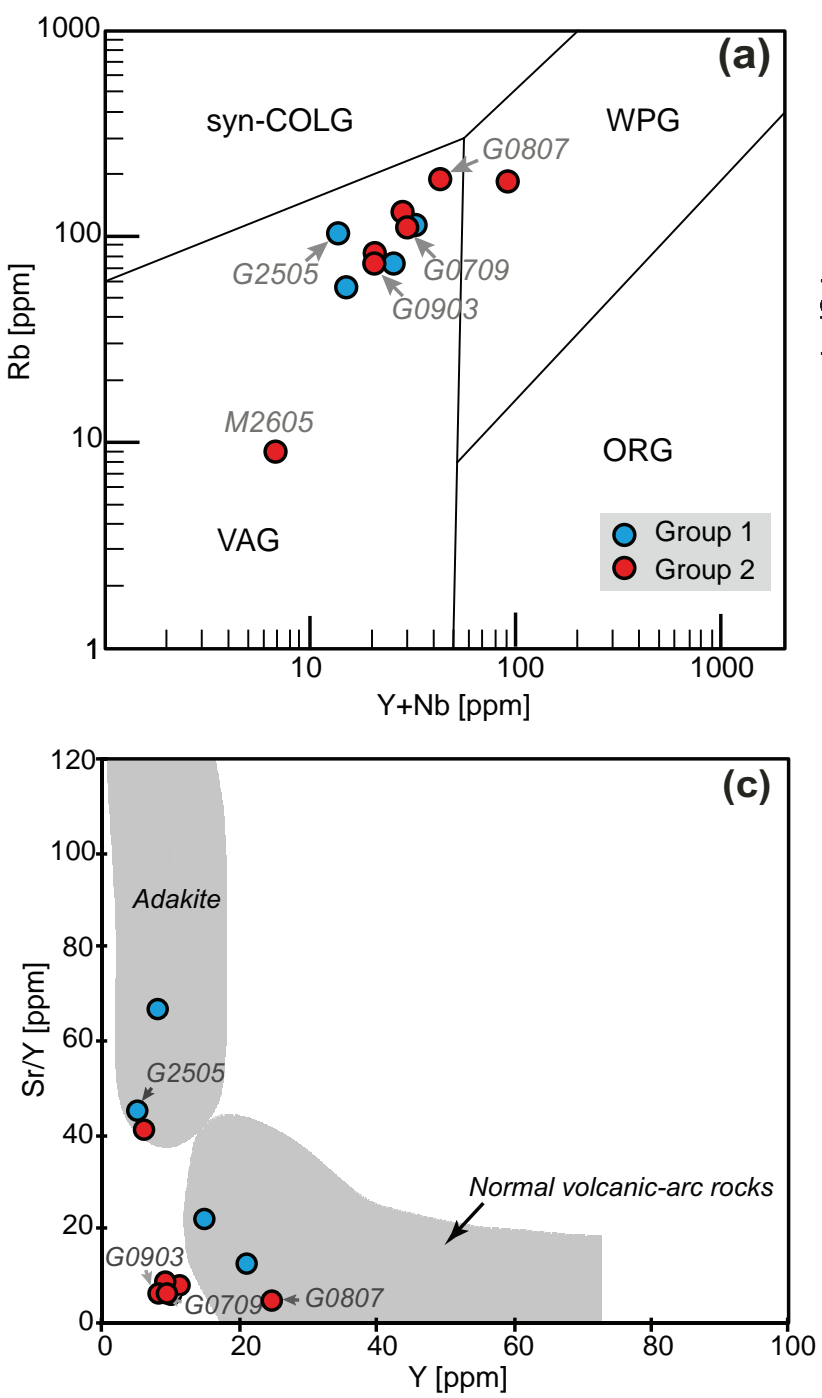

arc rocks to the adakite field on the Y vs. Sr/Y diagram (e.g., Defant et al. 1991). Most of the Group 2 samples show lower $\mathrm{Sr} / \mathrm{Y}$ ratios $(<10)$, only one has $\mathrm{Sr} / \mathrm{Y}$ reaching nearly 40.

The REE (Fig. 6a, c) and a broader selection of trace elements (Fig. 6b, d) are presented in spider diagrams normalized to Primitive mantle (Sun and McDonough 1989). Heavy rare-earth element (HREE) contents display large variations within each group, whereas light rareearth element (LREE) patterns are rather homogeneous. Group 1, however, shows higher $\mathrm{La}_{\mathrm{N}}$ and steeper LREE gradients (Fig. 6a), in accord with its definition based on elevated La and La/Gd values (Fig. 5b).

According to classification by Eby (1990) and Whalen et al. (1987), the high Mg-number and low value of $\mathrm{Zr}+$ $\mathrm{Nb}+\mathrm{Ce}+\mathrm{Y}(<200$ ppm; Tab. 2) in the studied samples indicates that they are not A-type granitoids, but S- or Itype. It is difficult to determine the type of the analyzed granitoids (S- or I types), because they plot at around the boundary of metaluminous and peraluminous fields (Fig.

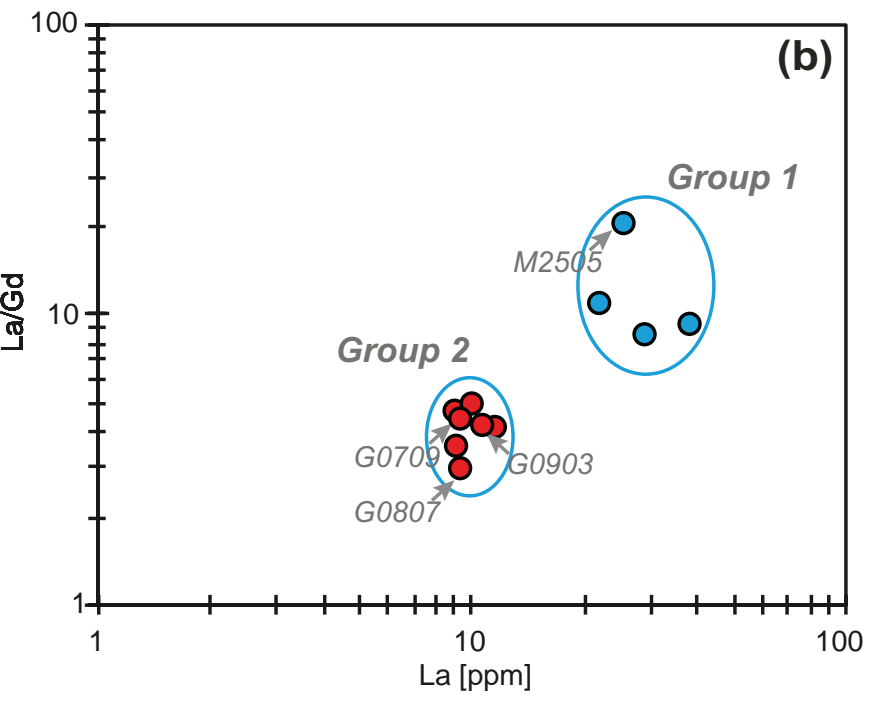

Fig. 5a $-\mathrm{Y}+\mathrm{Nb}$ vs. $\mathrm{Rb}$ tectonic discriminant diagram (Pearce et al. 1984). Syn-COLG $=$ syn-collisional granite, $\mathrm{WPG}=$ within-plate granite, $\mathrm{ORG}=$ ocean ridge granite, $\mathrm{VAG}=$ volcanic arc granite. $\mathbf{b}-$ La vs. La/Gd diagram. c - Y vs. Sr/Y diagram (Defant et al. 1991).

4b; e.g., Chappell and White 1974). However, absence of inherited zircon in the analyzed samples, and high $\mathrm{Na}_{2} \mathrm{O}$ contents (>3.2 wt. \% except for G0807) may suggest that these are I-type granites (e.g., Chappell and White 1974).

Group 1 granitoids are characterized by negative anomalies in $\mathrm{Nb}, \mathrm{Hf}, \mathrm{Zr}$ and $\mathrm{Ti}$, and no anomalies in $\mathrm{Ba}, \mathrm{Sr}$ and Eu (Fig. 6b). Group 2 granitoids have traceelement characteristics similar to each other, except for sample M2605 (Fig. 6d). Most of the Group 2 granitoids show negative anomalies in $\mathrm{Ba}, \mathrm{Sr}, \mathrm{Eu}, \mathrm{Zr}$, Ti and LREE. Sample M2605 has negative anomaly in Hf and positive anomaly in Sr.

\subsection{Zircon $U-P b$ dating of granitoids}

Our previous work (Burenjargal et al. 2014) revealed that sample M2505, which belongs to Group 1, yielded a Devonian age (385 $\pm 7 \mathrm{Ma})$. In this study, three Group 2 granitoid samples (G0709, G0903, and G0807) were selected for SHRIMP $\mathrm{U}-\mathrm{Pb}$ zircon age dating. These 
Tab. 2 Whole-rock trace-element (ppm) data from the Tseel area

\begin{tabular}{lrrrrrrrrrrr}
\hline Sample & M2605 & \multicolumn{1}{c}{ G1102 } & M2505 & M2701 & S0806 & G1103 & S0805 & G1101 & G0903 & G0709 & G0807 \\
\hline $\mathrm{Rb}$ & 8.9 & 55.9 & 103 & 83.7 & 113 & 184 & 113 & 72.6 & 74.8 & 133 & 193 \\
$\mathrm{Ba}$ & 78.2 & 979 & 894 & 204 & 125 & 223 & 1166 & 724 & 271 & 242 & 243 \\
$\mathrm{Th}$ & 2.9 & 6.6 & 8.1 & 5.5 & 10.7 & 17.9 & 13.1 & 19.1 & 14.0 & 9.0 & 13.0 \\
$\mathrm{Nb}$ & 0.6 & 7.2 & 8.8 & 9.9 & 25.1 & 81.2 & 15.1 & 5.0 & 12.0 & 18.4 & 18.6 \\
$\mathrm{Sr}$ & 256 & 531 & 237 & 92.1 & 50.8 & 64.2 & 339 & 271 & 74.8 & 69.6 & 114 \\
$\mathrm{Hf}$ & 1.1 & 1.5 & 1.2 & 2.1 & 2.1 & 5.1 & 1.8 & 1.7 & 3.2 & 2.7 & 2.9 \\
$\mathrm{Zr}$ & 16.3 & 32.4 & 21.5 & 46.7 & 30.5 & 62.5 & 44.5 & 37.7 & 67.1 & 47.7 & 67.3 \\
$\mathrm{Y}$ & 6.2 & 8.0 & 5.2 & 11.2 & 8.2 & 9.8 & 15.0 & 21.0 & 8.9 & 10.0 & 24.7 \\
$\mathrm{La}$ & 8.9 & 22.1 & 25.2 & 9.2 & 9.9 & 11.4 & 29.0 & 38.4 & 10.5 & 9.2 & 9.4 \\
$\mathrm{Ce}$ & 18.6 & 44.5 & 46.0 & 23.6 & 21.8 & 26.7 & 67.3 & 74.3 & 22.3 & 20.4 & 23.6 \\
$\mathrm{Pr}$ & 2.2 & 4.5 & 4.3 & 2.8 & 2.6 & 3.4 & 6.7 & 8.0 & 2.6 & 2.4 & 2.7 \\
$\mathrm{Nd}$ & 8.7 & 15.8 & 13.8 & 11.3 & 9.1 & 12.3 & 23.7 & 27.0 & 10.5 & 9.4 & 11.0 \\
$\mathrm{Sm}$ & 2.1 & 2.6 & 2.0 & 2.8 & 2.4 & 4.5 & 4.1 & 5.2 & 2.9 & 2.5 & 3.1 \\
$\mathrm{Eu}$ & 0.9 & 0.8 & 0.6 & 0.4 & 0.3 & 0.4 & 0.8 & 0.9 & 0.5 & 0.4 & 0.6 \\
$\mathrm{Gd}$ & 1.9 & 2.0 & 1.2 & 2.6 & 2.0 & 2.8 & 3.3 & 4.1 & 2.5 & 2.1 & 3.2 \\
$\mathrm{~Tb}$ & 0.3 & 0.3 & 0.2 & 0.4 & 0.3 & 0.4 & 0.5 & 0.6 & 0.4 & 0.3 & 0.6 \\
$\mathrm{Dy}$ & 1.5 & 1.5 & 1.0 & 2.7 & 1.5 & 2.2 & 2.9 & 3.5 & 1.9 & 2.1 & 3.9 \\
$\mathrm{Ho}$ & 0.2 & 0.3 & 0.1 & 0.5 & 0.3 & 0.4 & 0.6 & 0.8 & 0.3 & 0.4 & 0.9 \\
$\mathrm{Er}$ & 0.6 & 0.8 & 0.6 & 1.6 & 0.9 & 1.2 & 1.7 & 3.1 & 1.0 & 1.3 & 2.7 \\
$\mathrm{Tm}$ & 0.1 & 0.1 & 0.1 & 0.2 & 0.2 & 0.2 & 0.2 & 0.6 & 0.1 & 0.2 & 0.4 \\
$\mathrm{Yb}$ & 0.4 & 0.8 & 0.7 & 1.7 & 1.2 & 1.7 & 1.6 & 4.5 & 1.0 & 1.6 & 3.4 \\
$\mathrm{Lu}$ & 0.1 & 0.2 & 0.1 & 0.3 & 0.2 & 0.3 & 0.3 & 0.8 & 0.2 & 0.3 & 0.6 \\
\hline
\end{tabular}
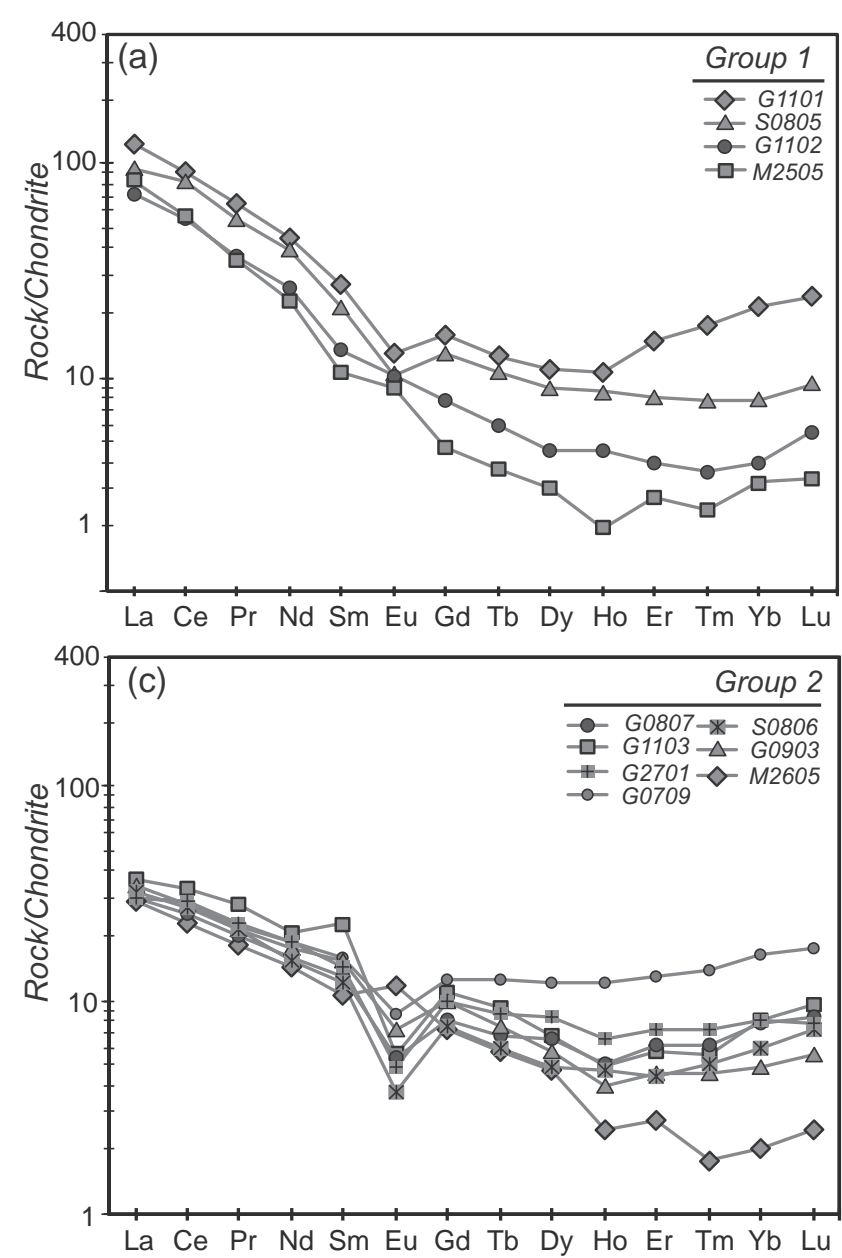

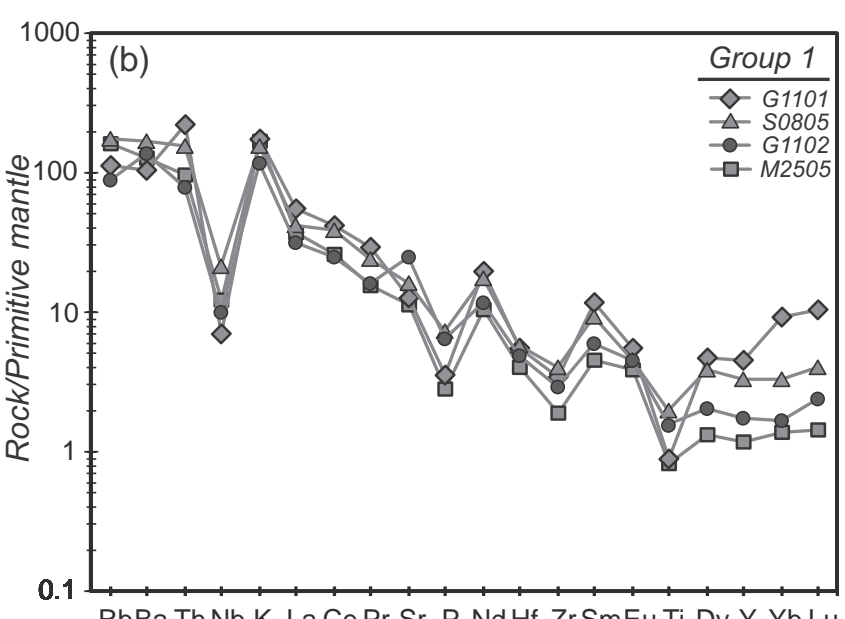

RbBaThNb K LaCePrSr P NdHf ZrSmEuTi Dy Y Yb Lu

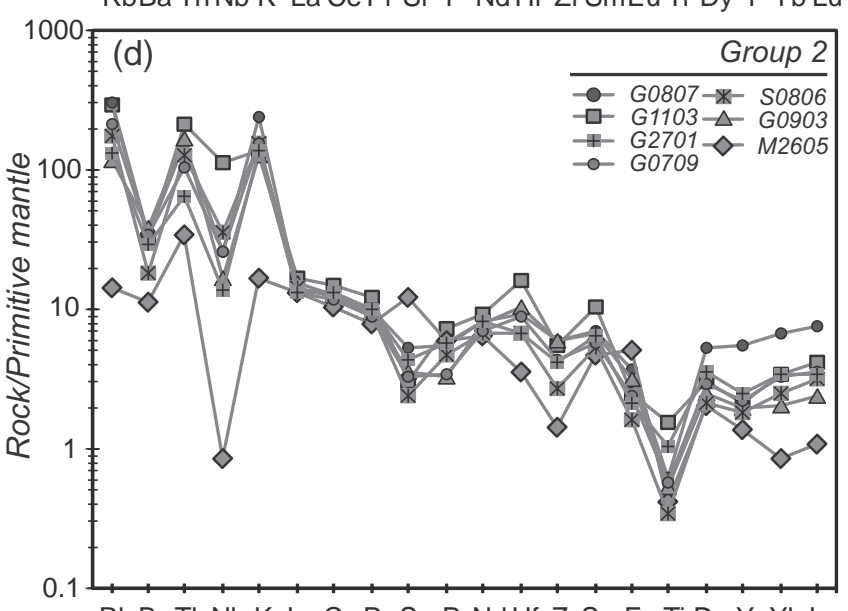

RbBaThNb K LaCePrSr P NdHf ZrSmEuTiDy Y YbLu 


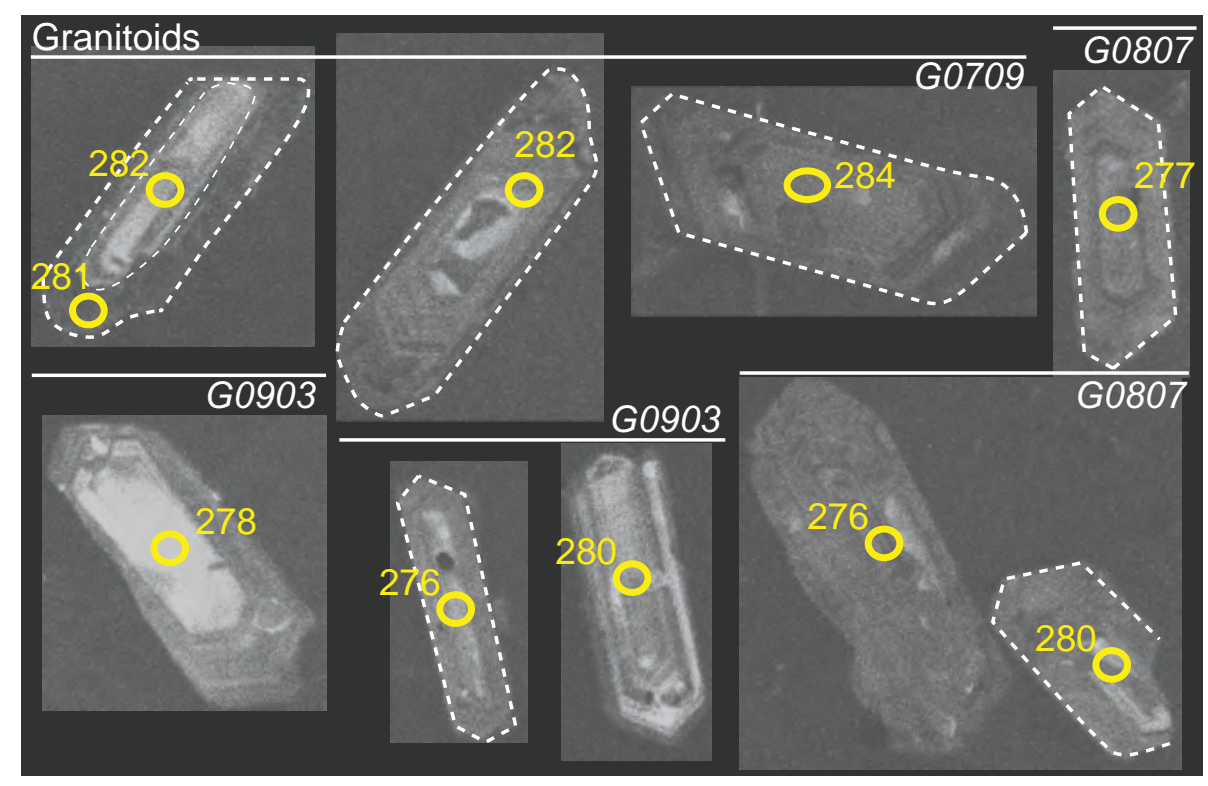

Fig. 7 Representative cathodoluminescence images of zircon grains from the dated granites (samples G0709, G0903, and G0807). Scale bar is 200 $\mu \mathrm{m}$ in all cases.

samples were collected from a granitoid body (G0903; Fig. 1c) and from granitoid veins (G0709 and G0807) which are concordant with pelitic gneiss (Fig. 2b) in the sillimanite zone of the Tseel area (Fig. 1c).

Representative cathodoluminescence (CL) images of zircons for dated samples are shown in Fig. 7. The granite samples contain large $(>100 \mu \mathrm{m})$ euhedral zircon grains. Zircon grains show oscillatory zoning, characterized by alternation of bright and dark zones. The most zircon cores display bright CL, while the mantles and rims are CL-dark.

The weighted mean age for granite $\mathbf{G 0 7 0 9}(\mathrm{n}=20)$ is $281.3 \pm 1.1 \mathrm{Ma}(2 \sigma ; \mathrm{MSWD}=1.3 ;$ Fig. $8 \mathrm{a}-\mathrm{b})$. The Th/U ratios range from 0.30 to 0.58 (Tab. 3).

The weighted mean age for granite G0903 $(\mathrm{n}=40)$ is $279.1 \pm 0.8 \mathrm{Ma}(\mathrm{MSWD}=1.3$; Fig. $8 \mathrm{c}-\mathrm{d})$. The $\mathrm{Th} / \mathrm{U}$ ratios of zircon range from 0.16 to 0.72 .

The weighted mean age for granite $\mathbf{G 0 8 0 7}(\mathrm{n}=15)$ is $278.0 \pm 1.6 \mathrm{Ma}(\mathrm{MSWD}=0.95$; Fig. $8 \mathrm{e}-\mathrm{f}$ ). The Th/U ratios of zircons range from 0.09 to 0.78 .

\section{Discussion}

\subsection{Contrasting geochemical features of the Devonian and Permian granitoids}

The ages of granitoids in the Tseel Terrane range from 580 to 270 Ma (Bibikova et al. 1992; Kozakov et al. 2002; Demoux et al. 2009; Jiang et al. 2012; Buren-

Fig. 6 Chondrite-normalized REE plots (Boynton 1984) and trace-element spider diagrams normalized to Primitive mantle (Sun and McDonough 1989) for a, b - Group 1 and c, d - Group 2 granitoids. jargal et al. 2014 and this work), with peaks in Middle Devonian (400-380 Ma) and Permian (277-282 Ma). However, it has been unclear so far how the geochemical characteristics of the granitoids vary with age.

In this study, we analyzed the whole-rock compositions of 11 granitoid samples from the Tseel area and identified two groups (Fig. 5b) with contrasting traceelement characteristics (Fig. 6). Although only four samples were dated [one Devonian (Burenjargal et al. 2014), and three Permian granitoids in this work], the Devonian sample is classified into Group 1 and the three Permian samples belong to the Group 2. Therefore, it is possible that the Group 1 and 2 granitoids formed in the Devonian and Permian, respectively. The $\mathrm{Y}+\mathrm{Nb}$ vs. Rb discrimination diagram (Fig. 5a) indicates that for both the Devonian and Permian granitoids the melts (or their sources) formed in a volcanic-arc setting.

The Devonian granitoids (Group 1) show negative anomalies in HFSE such as Nb, Hf, and Zr (Fig. $6 b$ ), indicating a contribution by fluids derived from a subducting slab (e.g., Pearce et al. 2005) or melting of ordinary upper continental crust. The large range in HREE concentrations among the samples can be produced by the fractionation of garnet (e.g., Irving and Frey 1978; Ma et al. 2015), indicating that melting occurred at depths within the stability field of garnet. As a consequence of relatively deep melting, several analyses fall in the adakite field in a $\mathrm{Sr} / \mathrm{Y}$ vs $\mathrm{Y}$ diagram (Fig. 5c) (Moyen 2009).

The geochemistry of the Permian granitoids (Group 2) is more evolved (see negative anomalies in $\mathrm{Sr}, \mathrm{Eu}, \mathrm{Ba}$ and Ti as well as depletion in LREE) than that of Group 1 , indicating fractionation of feldspars \pm biotite, monazite and opaque phase(s). 

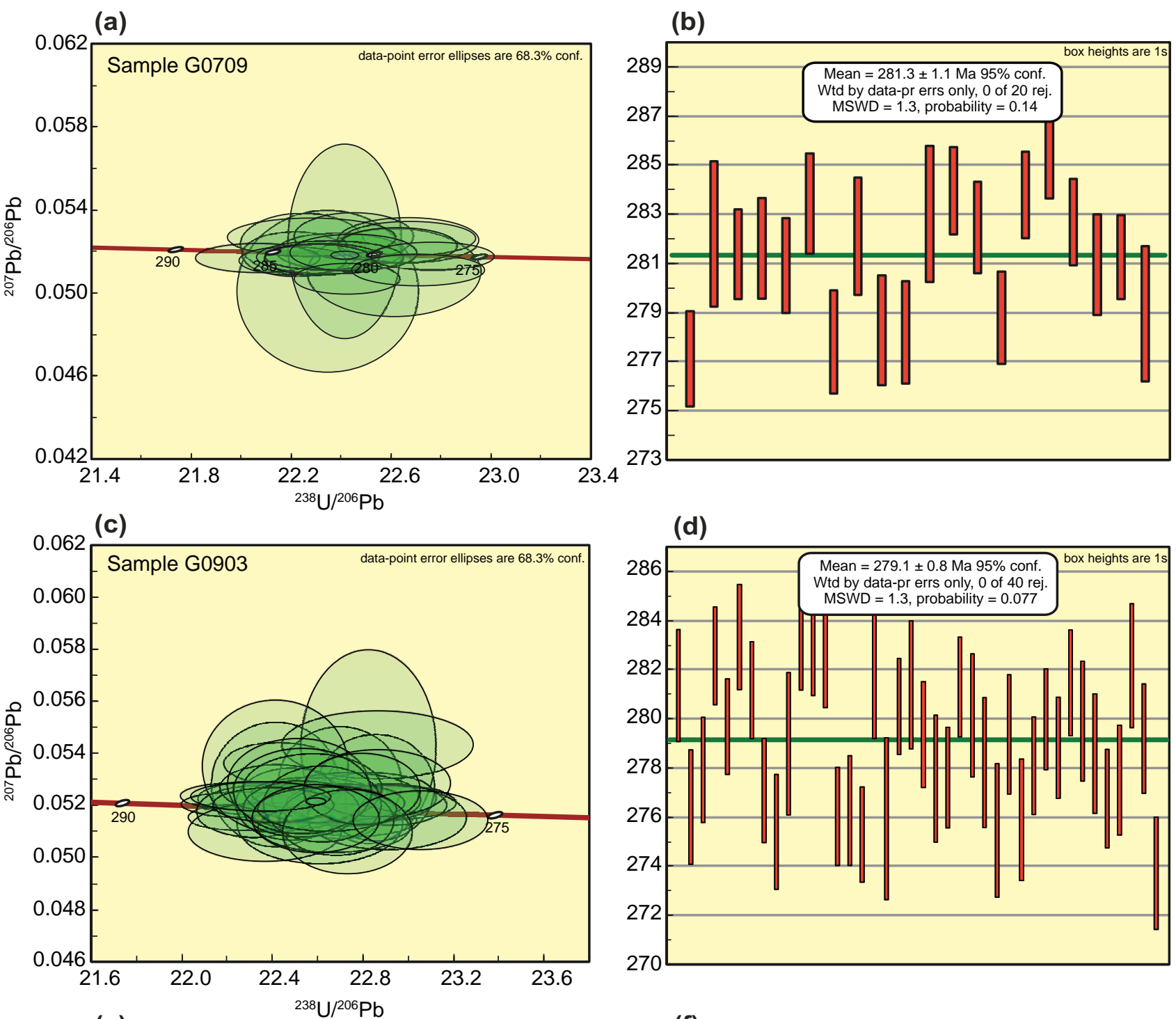

(e)
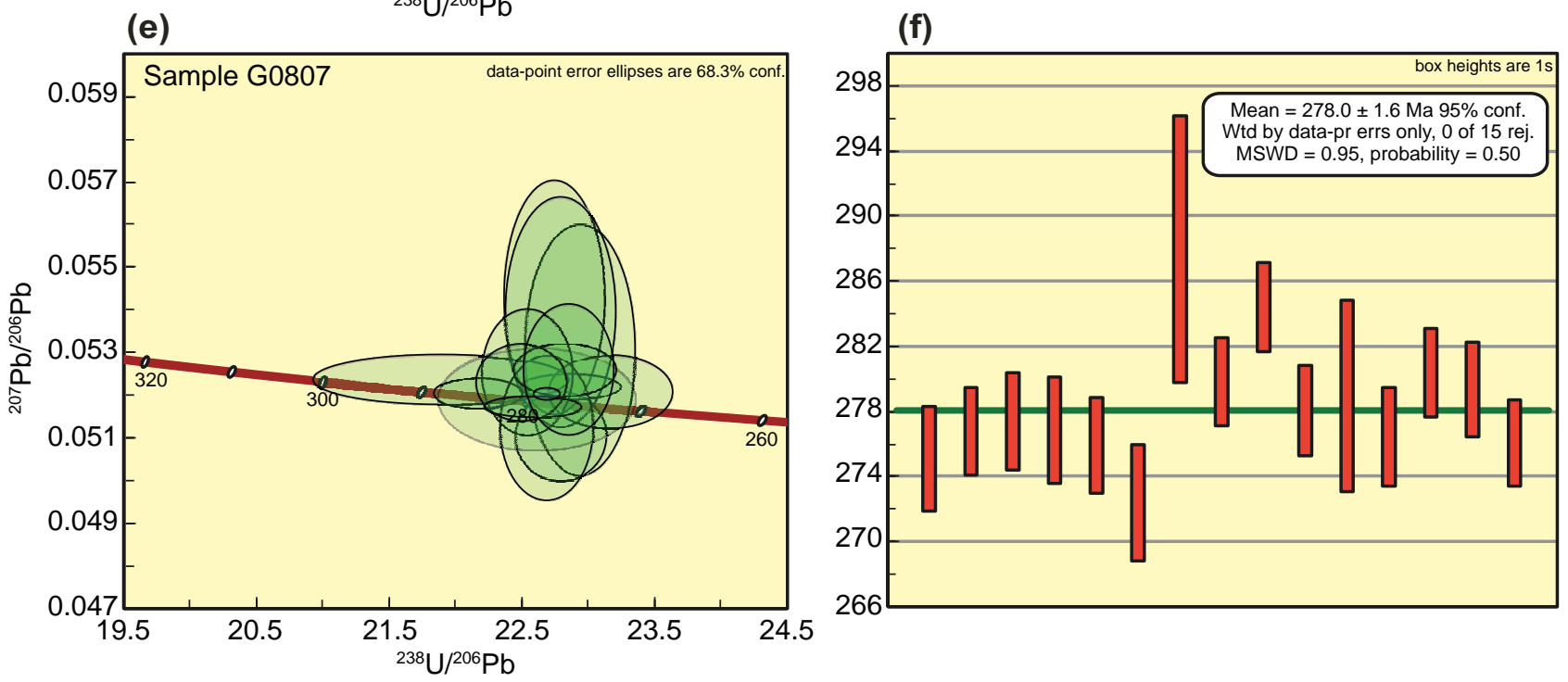

Fig. 8a, c, e - Tera-Wasserburg diagram of U-Pb zircon ages from granites G0709, G0903, and G0807. b, d, f - Comparison of all age data for samples G0709 $(n=20), G 0903(n=40)$, and G0807 $(n=15)$. The error ellipses in the concordia plots are $1 \sigma$. 


\subsection{Tectonic implications}

Based on petrological analyses of the garnet-bearing pelitic gneiss, the estimates of metamorphic $P-T$ conditions in the Tseel Terrane are roughly divided into two groups: high- $P$ and low- $T$ (Grt and St zones), and low- $P$ and high- $T$ (St, Sil, and Crd zones) (Burenjargal et al. 2014). The high- $P$ and low- $T$ conditions are $520-570^{\circ} \mathrm{C}$ and 4.5-7 kbar, in the kyanite stability field. The low- $P$ and high- $T$ conditions are $570-680{ }^{\circ} \mathrm{C}$ and $3-6$ $\mathrm{kbar}$, in the sillimanite stability field (Fig. 9; Burenjargal et al. 2014). The textural relationships among the three aluminosilicate polymorphs (Ky-SilAnd) in quartz veins reveal that they formed in the order of $\mathrm{Ky} \rightarrow \mathrm{Sil} \rightarrow$ And (Burenjargal et al. 2012, 2014), which suggests a transition from high- $P$ and low- $T$ conditions to low$P$ and high- $T$ conditions (Burenjargal et al. 2012). Such an evolution has been also reported from the Chinese Altai (Wei et al. 2007), which is the eastward continuation of the Tseel Terrane.

The results of zircon age dating of the metapelites in the Tseel area revealed that the high- $P$ and low- $T$ metamorphism occurred at 450-400 $\mathrm{Ma}$ and was followed by the low- $P$ and high- $T$ metamorphism at $377 \pm 30$ Ma (Burenjargal et al. 2014). Based on the spatial correlation between granitoid distribution and peak temperature distribution of pelitic gneisses, Burenjargal et al. (2014) suggested that Devonian granitoids ( $385 \pm 7 \mathrm{Ma}$ ) were the possible heat source responsible for a high geothermal gradient at middle to upper crustal levels (10-20 km depth) during the Middle Devonian (377 $\pm 30 \mathrm{Ma}$ ) (Fig. 9). The signature of garnet fractionation in the Devonian granitoids (i.e., the HREE trends in Fig. 6a) is consistent with the deep source of the granitic melts, which could have heated the surrounding pelitic gneisses.

Given the negative anomalies of $\mathrm{Nb}, \mathrm{Hf}, \mathrm{Zr}$ and Ti (Fig. 6b), the pa-

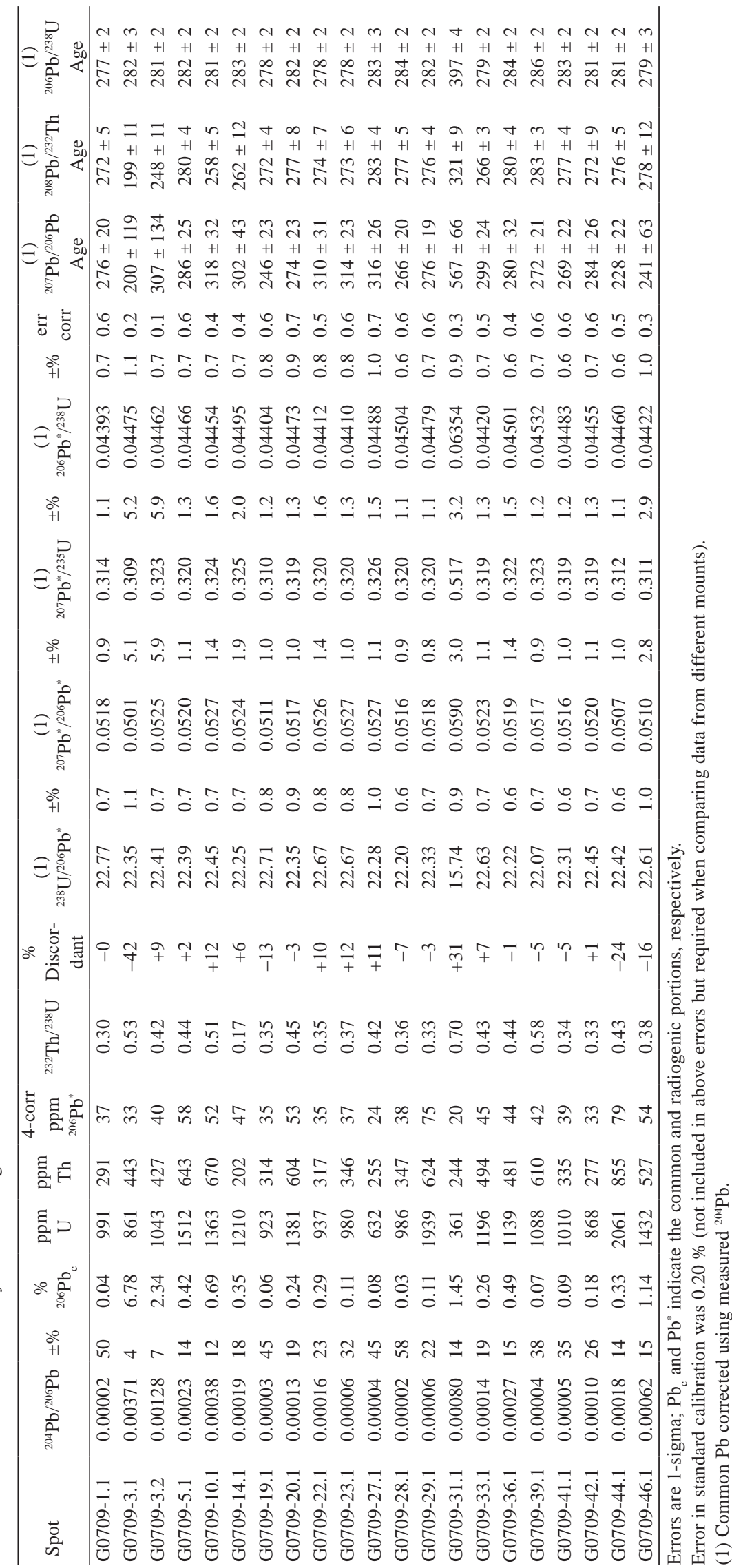




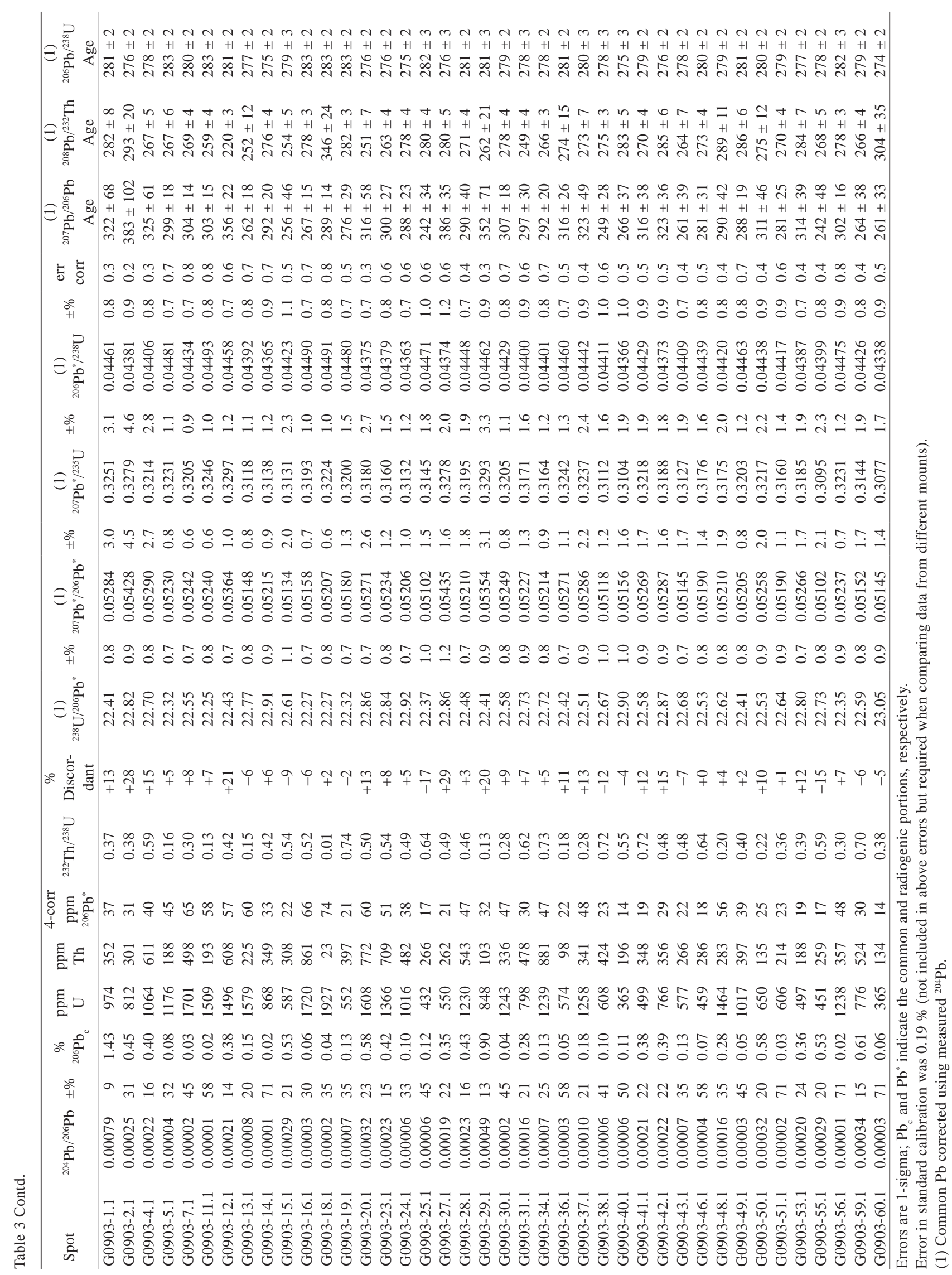




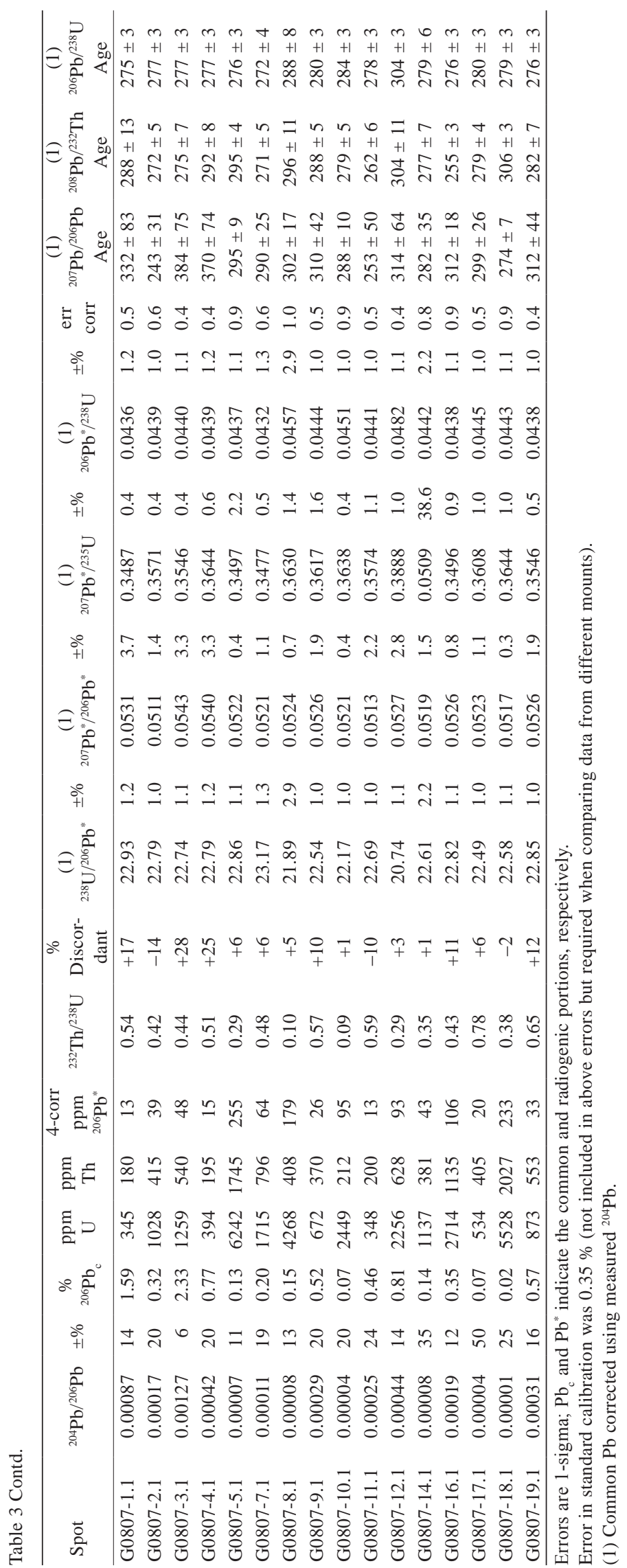

rental magmas could have been produced in a subduction zone setting, catalyzed by slab-derived fluids, or by melting of upper continental crust. In contrast, the $\sim 280$ Ma Permian granitoids, including the bodies analyzed in this study (Figs 1c, 8), were emplaced after the main metamorphic events (Fig. 9). The $P-T$ evolution and its relation to the granitoid bodies of the Tseel Terrane (Fig. 9) shows similarity to those during the crustal evolution of the other orogenic belts, including the Hercynian crustal section in the Serre Massif, in the southern Italy (e.g., Angi et al. 2010).

In summary, high- $P$ and low- $T$ metapelitic rocks of the Tseel area occurred in close relationship to Devonian granitic magmatism, perhaps in a subduction zone setting. Consequently, the conditions of metamorphism in the area changed from high- $P$ and low-T (450-400 Ma) to low- $P$ and high- $T$ (377 \pm 30 Ma) (Burenjargal et al. 2014). The Permian granitoids intruded after the low- $P$ and high- $T$ regional metamorphism.

\section{Conclusions}

We documented the geochemical characteristics of Devonian and Permian granitoids in the Tseel area of the Tseel Terrane, SW Mongolia. Presented are three new Permian (281-271 Ma) zircon SHRIMP ages for granitoids in the central part of the Tseel area. In spite of the differences in age, the studied granitoids all share a geochemical signature of arcrelated magmatism. On the $\mathrm{La}-\mathrm{La} / \mathrm{Gd}$ diagram, the 11 granitoid samples are classified into two groups. The Primitive-mantle normalized spiderplots for Devonian granitoid samples (Group 1) are characterized by negative anomalies in $\mathrm{Nb}, \mathrm{Hf}, \mathrm{Zr}$ and $\mathrm{Ti}$, indicating the contribution of slab-derived fluids or melting of upper continental crust. In contrast, Group 2, which includes all the Permian samples, shows negative anomalies in $\mathrm{Ba}, \mathrm{Sr}$, and $\mathrm{Eu}$, documenting fractionation of feldspars with or without, biotite. The depletion in LREE and Ti in addition underlines the importance of monazite and opaque mineral(s) fractionation.

These features, combined with the results of previous petrological and geochronological studies of the pelitic gneisses, suggest that the Devonian granitoids intruded into the middle crustal levels, resulting in regional high-temperature metamorphism, whereas the Permian granitoids were emplaced at relatively shallower levels, after the main metamorphic events. 


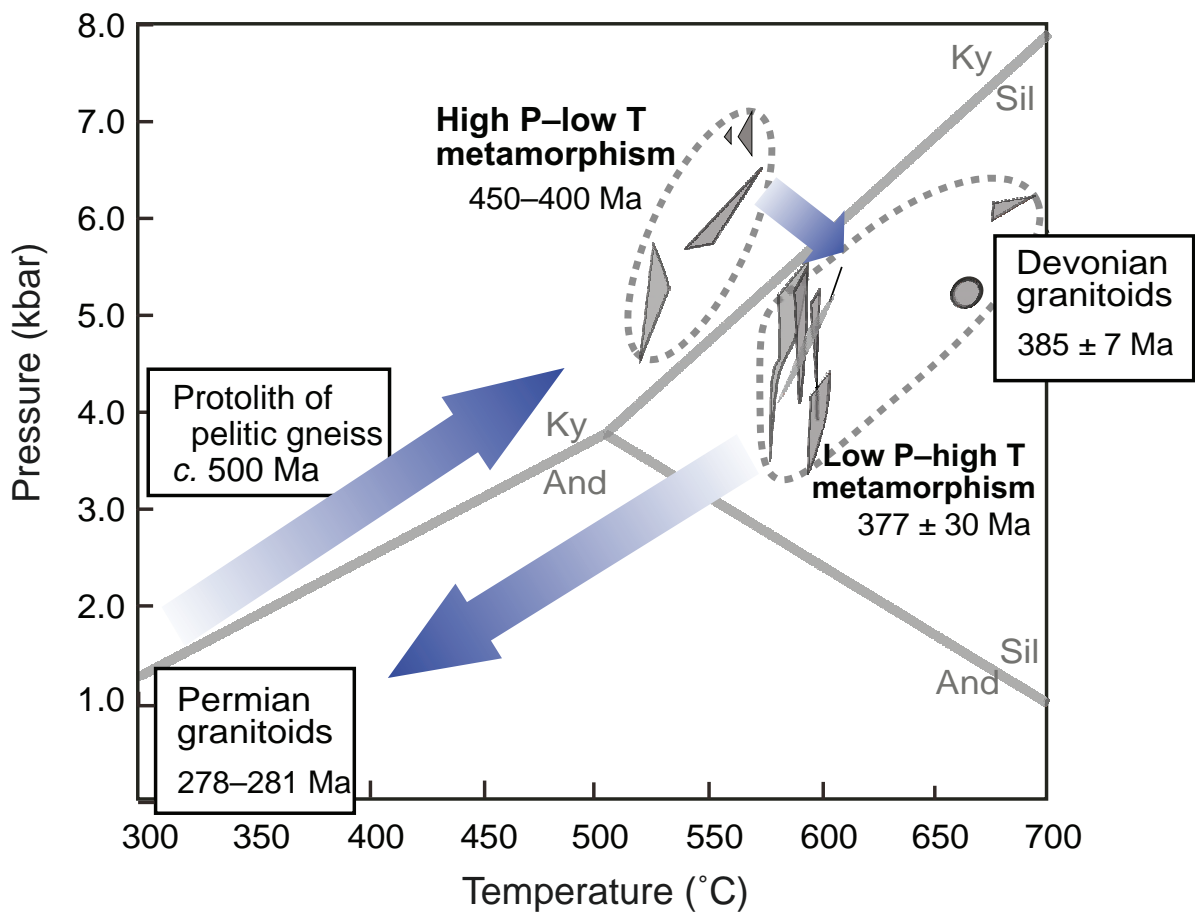

Fig. 9 Schematic $P-T-t$ diagram showing the metamorphic evolution of the Tseel Terrane and the timing of granitoid intrusions. Grey triangles indicate the $P-T$ conditions estimated by Burenjargal et al. (2014), and arrows are inferred from the timing relationships among the aluminosilicate polymorphs [kyanite $(\mathrm{Ky}) \rightarrow$ sillimanite (Sil) $\rightarrow$ andalusite (And)], and garnet zoning (Burenjargal et al. 2012, 2014).
Acknowledgements. Constructive reviews by M. Kohút and V. Janoušek and two anonymous referees and editorial handling by K. Schulmann are greatly acknowledged. The authors thank O. Gerel, J. Lkhamsuren, B. Munkhtsengel, B. Batkhishig, and A. Chimedtseren (School of Geology and Mining Engineering, Mongolian University of Science and Technology) for their help and advice. D. Tsendbazar is thanked for providing assistance in the field. We are also grateful to S. Yamasaki, R. Yamada, and T. Watanabe for help with the XRF and ICP-MS analyses. This research was funded by the Global COE program of Tohoku University, Japan.

\section{References}

Amelin Y, Stern R, Krot AN (2003) Distribution of U, Th, $\mathrm{Pb}$ and $\mathrm{Nd}$ between minerals in chondrules and CAIs. In: Proceedings of the $34^{\text {th }}$ Annual Lunar and Planetary Science Conference, March 17-21, 2003, League City, Texas, abstract no. 1200

Angi G, Cirrincione R, Fazio E, Fiannacca P, Ortolano G, Pezzino A (2010) Metamorphic evolution of preserved Hercynian crustal section in the Serre Massif (CalabriaPeloritani Orogen, southern Italy). Lithos 115: 237-262

Badarch G, Cunningham WD, Windley BF (2002) A new terrane subdivision for Mongolia: implications for Phanerozoic crustal growth of Central Asia. J Asian Earth Sci 21: 87-110

Bibikova YEV, Kirnozova TI, Kozakov IK, Kotov AB, NeyMARK LA, GorkHovsKiy BM, SHULESHKo IK (1992) U-Pb ages for polymetamorphic complexes on the southern flank of the Mongolian and Govi Altai. Geotectonics 26: 166-172

Black LP, Kamo SL, Allen CM, Davis DW, Aleinikoff JN, Valley JW, Mundil R, Campbell IH, Korsch RJ, Williams IS, Foudoulis C (2004) Improved ${ }^{206} \mathrm{~Pb}-{ }^{238} \mathrm{U}$ microprobe geochronology by the monitoring of a traceelement-related matrix effect; SHRIMP, ID-TIMS, ELAICP-MS and oxygen isotope documentation for a series of zircon standards. Chem Geol 205: 115-140

Boynton WV (1984) Geochemistry of the rare earth elements: meteorite studies. In: Henderson P (ed) Rare Earth Element Geochemistry. Elsevier, Amsterdam, pp 63-114

Broussolle A, Štípská P, Lehmann J, Schulmann K, Hacker BR, Holder R, Kylander-Clark ARC, HanžL P, Racek M, Hasalová P, Lexa O, HrdličKová K, Buriánek D (2015) P-T-t-D record of crustal-scale horizontal flow and magma-assisted doming in the SW Mongolian Altai. J Metamorph Geol 33: 359-383

Burenjargal U, Okamoto A, Meguro Y, Tsuchiya N (2012) An exhumation pressure-temperature path and fluid activities during metamorphism in the Tseel Terrane, SW Mongolia: constraints from aluminosilicate-bearing quartz veins and garnet zonings in metapelites. J Asian Earth Sci 54-55: 214-229

Burenjargal U, Okamoto A, Kuwatani T, Sakata S, Hirata T, Tsuchiya N (2014) Thermal evolution of the Tseel Terrane, SW Mongolia and its relation to granitoid intrusions in the Central Asian Orogenic Belt. J Metamorph Geol 32: 765-790

Chappell BW, White AJM (1974) Two contrasting granite types. Pacific Geol 8: 173-174 
Claoué-Long JC, Compston W, Roberts J, Fanning CM (1995) Two Carboniferous ages: a comparison of SHRIMP zircon dating with conventional zircon ages and ${ }^{40} \mathrm{Ar} /{ }^{39} \mathrm{Ar}$ analysis. In: Berggren WA, Kent DV, Aubrey MP, Hardenbol J (eds) Geochronology Time Scales and Global Stratigraphic Correlation. Society Sedimentary Geology Special Publications 54: pp 3-21

Compston W, Williams IS, Meyer CE (1984) U-Pb geochronology of zircons from lunar breccia 73217 using a sensitive high-mass resolution ion microprobe. J Geophys Res B 89: 525-534

Defant MJ, Richerson PM, De Boer JZ, Stewart RH, Maury RC, Bellon H, Drummond MS, Feigenson MD, JACKSON TE (1991) Dacite genesis via both slab melting and differentiation: Petrogenesis of La Yeguada Volcanic Complex, Panama. J Petrol 32: 1101-1142

Demoux A, Kröner A, Hegner E, Badarch G (2009) Devonian arc-related magmatism in the Tseel Terrane of SW Mongolia: chronological and geochemical evidence. J Geol Soc, London 166: 459-471

EBy GN (1990) The A-type granitoids - a review of their occurrence and chemical characteristics and speculations on their petrogenesis. Lithos 26: 115-134

Horie K, Hidaka H, Gauthier-Lafaye F (2006) Elemental distribution in zircon: alteration and radiation-damage effects. Phys Chem Earth 31: 587-592

IRVINE TN, BARAGAR WRA (1971) A guide to the chemical classification of the common volcanic rocks. Can J Earth Sci 8: 523-548

Irving AJ, Frey FA (1978) Distribution of trace-elements between garnet megacrysts and host volcanic liquids of kimberlitic to rhyolitic composition. Geochim Cosmochim Acta 42: 771-787

JAHN BM, Wu FY, CHen B (2000) Granitoids of the Central Asian Orogenic Belt and continental growth in the Phanerozoic. Trans Roy Soc Edinb, Earth Sci 91: 181-193

Jiang Y, Sun M, Kröner A, Tumurkhuu D, Long X, Zhao G, Yuan G, Xiao W (2012) The high-grade Tseel Terrane in SW Mongolia: an Early Paleozoic arc system or a Precambrian sliver? Lithos 142-143: 95-115

Khain EV, Bibikova EV, Kröner A, Zhuravlev DZ, Sklyarov EV, Fedotova AA, KravchenKo-Berezhnoy IR (2002) The most ancient ophiolite of the Central Asian fold belt: $\mathrm{U}-\mathrm{Pb}$ and $\mathrm{Pb}-\mathrm{Pb}$ zircon ages for the Dunzhugur Complex, Eastern Sayan, Siberia, and geodynamic implications. Earth Planet Sci Lett 199: 311-325

Kozakov IK, Glebovitsky VA, Bibikova EV, Azimov PY, KIRNOZOVA TI (2002) Hercynian granulites of Mongolian and Gobian Altai: geodynamics setting and formation conditions. Doklady Earth Sci 386: 781-785

Ludwig KR (2008) User's Manual for Isoplot 3.6. A Geochronological Toolkit for Microsoft Excel. Berkeley Geochronology Center Special Publications 4: pp 1-77
Ludwig KR (2009) SQUID 2 (rev. 2.50). A User's Manual. Berkeley Geochronology Center Special Publications 5: pp 1-104

Ma Q, Sheng JP, Xu YG, Griffin WI, Zhang RS (2015) Are continental "adakites" derived from thickened or founded lower crust? Earth Planet Sci Let 419: 125-133

Maniar PD, Piccoli PM (1989) Tectonic discrimination of granitoids. Geol Soc Am Bull 101: 635-643

Middemost EAK (1994) Naming materials in the magma igneous system. Earth Sci Rev 37: 215-224

Moyen JF (2009) High Sr/Y and La/Yb ratios: the meaning of the "adakitic signature". Lithos 112: 556-574

Pearce JA, Harris NBW, Tindle AG (1984) Trace element discrimination diagrams for the tectonic interpretation of granitic rocks. J Petrol 25: 956-983

Pearce JA, Stern RJ, Bloomer SH, Fryer P (2005) Geochemical mapping of the Mariana arc-basin system: implications for the nature and distribution of subduction components. Geochem Gephys Geosys Q07006

Rippington S, Cunningham D, England R (2008) Structure and petrology of the Altan Uul Ophiolite: new evidence for a Late Carboniferous suture in the Gobi Altai, southern Mongolia. J Geol Soc, London 165: 711-723

StACEY JT, KRAMERS JD (1975) Approximation of terrestrial lead isotope evolution by a two-stage model. Earth Planet Sci Lett 26: 207-221

Sun S, McDonough WF (1989) Chemical and isotopic systematics of oceanic basalts: implications for mantle composition and processes. J Geol Soc, London 42: 313-345

ŞENGÖR AMC, NATAL'In BA, Burtman VS (1993) Evolution of the Altaid tectonic collage and Paleozoic crustal growth in Eurasia. Nature 364: 299-307

Wei C, Clarke G, Tian W (2007) Transition of metamorphic series from the kyanite- to andalusite-types in the Altai Orogeny, Xinjiang, China: evidence from petrography and calculated KMnFMASH and KFMASH phase relations. Lithos 96: 353-374

Whalen JB, Currie KL, Chappell BW (1987) A-type granites: geochemical characteristics, discrimination and petrogenesis. Contrib Mineral Petrol 95: 407-419

WiLliAMS IS (1998) U-Th-Pb geochronology by ion microprobe. In: McKibien MA, Shanks WCP, Ridley WI (eds) Applications of Microanalytical Techniques to Understanding Mineralizing Processes. Reviews in Economic Geology 7: Society of Economic Geologists, Littleton, CO., USA, pp 1-35

Windley BF, Alexeiev D, Xiao W, Kröner A, Badarch G (2007) Tectonic models for accretion of the Central Asian Orogenic Belt. J Geol Soc, London 164: 31-47

YAMASAKI S (1996) Inductively coupled plasma mass spectrometry. In: Boutton T, Yamasaki S (eds) Mass Spectrometry of Soils. Marcel Dekker, New York, pp 459-491

YAMASAKI S (2000) Inductively coupled plasma mass spec- 
trometry in environmental analysis. In: Meyer RA (ed) Encyclopedia of Analytical Chemistry. John Wiley \& Sons, Chichester, pp 2672-2692
Zonenshain LP, Suyentenko OD, Jamyandamba L, Eengin G (1975) Structural and the axial part of South Mongolian eugeosyncline in the Dzolen Range. Geotectonics 9: $214-220$ 